\title{
(息)
}

Citation:

Moss, D (2010) Memory, space and time: Researching children's lives. Childhood, 17 (4). 530 - 544. ISSN 0907-5682 DOI: https://doi.org/10.1177/0907568209345611

Link to Leeds Beckett Repository record:

https://eprints.leedsbeckett.ac.uk/id/eprint/320/

Document Version:

Article (Accepted Version)

The aim of the Leeds Beckett Repository is to provide open access to our research, as required by funder policies and permitted by publishers and copyright law.

The Leeds Beckett repository holds a wide range of publications, each of which has been checked for copyright and the relevant embargo period has been applied by the Research Services team.

We operate on a standard take-down policy. If you are the author or publisher of an output and you would like it removed from the repository, please contact us and we will investigate on a case-by-case basis.

Each thesis in the repository has been cleared where necessary by the author for third party copyright. If you would like a thesis to be removed from the repository or believe there is an issue with copyright, please contact us on openaccess@leedsbeckett.ac.uk and we will investigate on a case-by-case basis. 


\title{
Moss, D. (Forthcoming) 'Memory, Space and Time: Researching Children's Lives' Childhood: Journal of Global Child Research
}

\begin{abstract}
This article discusses the research approach in 'Pathways through Childhood', a small qualitative study drawing on memories of childhood. The research explores how wider social arrangements and social change influence children's everyday lives. The article discusses the way that the concepts of social memory, space and time have been drawn on to access and analyze children's experiences arguing that attention to the temporal and spatial complexity of childhood reveals less visible yet formative influences and connections. Children's everyday engagements involve connections between past and present time, between children, families, communities and nations, and between different places. Children carve out space and time for themselves from these complex relations.

Childhood memory space time society
\end{abstract}




\section{Memory, Space and Time: Researching Children's Lives}

\section{Introduction}

This article discusses the research approach in relation to findings from 'Pathways through Childhood'; a small qualitative study drawing on memories of childhood. The research examines the influence of social arrangements and change in childhood related to war, migration, employment, policing, technology, popular culture and religion, considering the ways these influence children whether or not they are directly caught up in events. The central questions are, 'How do wider social, cultural, economic and political events and systems influence children's everyday lives? How do children practice childhood in relation to these influences?' This article focuses particularly on the way that the sensitizing concepts of memory, space and time have been drawn on to access and analyze children's experiences, arguing that this approach deepens understanding of children's lives by making visible previously under-researched aspects of experience. Attention to the wider social landscape and children's engagement enriches understanding of their everyday lives.

The research is one of a number of studies that explore children's engagement in adult worlds, broadening the focus from arenas conventionally associated with childhood (Brannen 2004, Morrow 2003, Neale and Flowerdew 2003, Thomson et al. 2002, Aitken 2001, Holloway and Valentine 2000). These draw on a combination of ideas from social geography (Massey 2005, Lefebvre 1991) the sociology of 'time' (Adam 1990, 1995, 1998, 2006) and a range of materialist and post-structural sociological approaches. The 'Pathways' research draws on different, sometimes competing schools of thought to give visibility to the ways that children's everyday experiences connect to wider social arrangements. It considers the effects of social position, social division, the influence of family, state, community and nation and the ways children carve out space and time for themselves. The canvas of the research is broad and the sample relatively small. The aim is to give attention to some important but less researched areas of children's experience. Space, time and social memory are drawn on as sensitizing concepts to facilitate this.

\section{Research methodology: the sensitizing concepts of memory, space, time and childhood}

It is well established that sensitivity to space-time in research helps generate rich data and contextualise, ground and analyse this (Urry 1996). Space and time are complex concepts with different interpretations, both quantitative and qualitative. Ideas about the social production of space and temporality have informed the research from the outset. The research is also based on memory and ideas about personal and social memory are drawn on. Sociological understanding of memory, space and time enriches research by facilitating lines of research 
enquiry from children's lives to significant 'behind the scenes' influences (Layder 1993 p. 249). These three concepts are now discussed in turn.

First, Halbwachs (1925/1992) distinguishes between different forms of memory, drawing attention to the ways personal memories are channelled through familial and other collective memories. These 'social memories' provide 'social frameworks' for engaging with the everyday. The way society is arranged reflects social memories as current social arrangements are based on past human practices. Each social encounter is therefore also an encounter with the past. The 'Pathways' research explores the relationship between children's experience and collectivised forms of memory related to family, community and nation. Social memories are considered as part of the 'present' time of childhood.

The second concept is 'the social production of space' (Lefebvre 1991). Lefebvre argues that places are historically produced from interaction. Space has a threefold character. First, space is 'practice' as there are everyday routes through space people are required to follow. Consider, for example, the way children's movement between public and private spheres has changed over time.

Secondly, space is 'representation' as meanings are associated with places. These may encourage entry for some and deter others. The concept 'landscape' is drawn on to explore space as representation (ibid). Thirdly, space is 'representational' as it is both living and lived. Children actively engage with the landscapes they occupy. Space contains and conveys social memories of times past. Combining Halbwachs' approach to memory with this approach to space enables lines of research enquiry to be drawn from personal experiences to the landscapes children occupy and how they interpret, negotiate and move through these. The power relations contained there and the 'boundaries on the ground' also become visible (Ardener 1993:11).

Of equal significance is the third concept, 'temporality'. Temporal influences in childhood (Adam 1995) involve the bodily times of development, times of the household, school, industry and environment. Childhood is a time of complex transition. 'Life is different from physics,' (Jaques 1982/1990: 22); our sense of time involves, '....memories in the present of the past, expectations and desires in the present of the future.' Lines of research enquiry may be drawn from children's experiences to the complex temporal influences shaping childhood. Children's everyday lives are complex temporal engagements that involve carving out space and time for themselves (Davies 1990).

The sociological concepts of memory, space and time overlap yet are different and open to interpretation. If used imaginatively, in different combinations, they facilitate consideration of a wide range of influences in childhood that otherwise may be overlooked. The dangers of seeing children's lives as overly determined by social structures and adult worlds or as restricted to particular arenas such as home and school may be avoided. It is important to consider children's perspectives, experiences and the events influencing their lives which might be 
outside their understanding. These include the influences of the wider social (and natural) environment and events distant in time.

\section{Research methods: accessing children's experiences through space and time}

The concepts discussed above have been drawn on to access children's experiences in relation to the research questions ${ }^{1}$. The sample involves sixteen adult respondents, selected for two reasons. The first is the diversity of their experiences as children. They come from different social class backgrounds, ethnicities, generations, faith communities, colour, gender, sexual orientation and disability. The research is based in England, but a significant number experienced part of their childhood outside England including in Northern Ireland, Pakistan, India, Italy, the Caribbean, Nigeria and South Africa. The second is their professional and academic commitment to children's rights and their willingness to give up their time to research that is intended to deepen understanding of children's lives. This choice of sample made it possible to draw on a wide canvas of childhood experience, to explore different times and places, and to consider different children's engagement, with children's interests in mind. The span of childhood remembered is from the 1950s-1980s.

Developing space-time concepts as research tools is complex. Too rigid an approach restricts the visibility of important processes, for example, attempts to log events in relation to the clock and map uses of space overlook both simultaneity and the meanings attached to space and time (Urry 1991, Rose 1993, Saraswathi 1994). On the other hand, space-time concepts may be too generic to be useful. It is important to draw on concepts that make particular spatial and temporal relations visible.

The concepts of space and time were separately associated with different research tools. This accorded with meanings of space and time as respondents understood them and meant their childhood experience was viewed through the lenses of space and time separately. This material could then be triangulated. In relation to the research analysis however, the concepts of space and time were used in more overlapping ways (see next section). The research tools were threefold. The first was a guided semi-structured interview. Respondents were invited to share memories of particular social experience related to war, migration, employment and so forth (see introduction). They were told these memories could be direct experience, familial stories or other indirect experience. This created legitimate space to share other people's memories and provided one means of accessing social memories. Ideas about time, social change and memory shaped the design. The second tool also involved a guided interview. Here the focus was the influences of place and the social production of space. Respondents were asked for recollections of the places of childhood in relation to aspects of living such as play, learning, working, travelling etc. The diversity of 
their experience involved different living arrangements and geographical connections. The focus was the child moving through the setting and ideas about memory, space and childhood informed the design. The third tool was a structured questionnaire designed to gather concrete data related to social and familial position and transitions across space-time, such as geographic and social mobility. Data elicited related to the child, parents (or carers), grandparents and some extended family. Ideas about family, mobility and social divisions informed the design.

\section{Research analysis: understanding children's social involvement through memory, space and time.}

When re-considering the literature and data gathered in relation to the influence of wider social arrangements in childhood, five overlapping questions emerged. First, as social arrangements are constructed and conceptualised through selective social memory, how does this shape children's experience? Secondly, as memory takes different forms (personal and social) how do these inter-relate in children's lives? Thirdly, what are the effects of movement through space and time, including encounters with new places and communities? Fourthly, the selectivity of social memory leads to silences in the social memory. What are the implications of this? Fifthly, in light of complex space-time relations, how do children carve out space-time for themselves? These questions are now considered in turn.

\section{The selectivity of social memory and childhood ${ }^{2}$}

In relation to personal memories of childhood, Misztal (2003) asks whether they are real, fictional or recollections of stories told; whether they are singular or clusters of events. Memory involves direct and indirect experience that is sometimes hard to distinguish. Similar questions arise in relation to familial and other collective memories. Familial memory involves the selective development of archives, including photographs, film, letters, stories and memorabilia (Misztal ibid). Collective memory involves the selective development of public symbols, 'traditions', rituals, institutional practices (ibid) and the social production of spatial arrangements (Lefebvre 1991). Social arrangements experienced in childhood involve selective memories of times past, developed in relation to particular interests (Hobsbawm and Ranger 1983). The power of social memory relates to this selectivity, 'Interpersonal rehearsal plays an important role in maintaining and consolidating ... memories' (Misztal 2003: 81 citing Finkenauer et al. 1997). Social memories become anchored in social arrangements through dissemination and repetition, influencing the 'present time' of childhood.

Some aspects of family experience are shared repeatedly with children; others are hidden. Apara repeats the story of her grandmother, recounted to her in 
childhood. Apara was born in Nigeria and moved to England when 5, in the 1970s. Her mother is from an English working class heritage and her father, upper class Nigerian. The story emerges from the economic depression in England, thirty years before Apara was born. Her grandmother worked in a meat factory during the 1930s,

.... my grandmother ... basically kept the family going ... also her sister's family... she worked in a factory... that made meat products. She used to look after the pigs ... For years, she kept [the two families] fed, by wearing [wellingtons] to work and stuffing pounds of sausages down [them] by winding them round her legs ... So when you think of the weight of them, and having to normally walk.

This is a story of a 'heroine' committed to her family's welfare. The memory shared with the child celebrates this containing education about the potential of women to overcome adversity. The undercurrent is hunger associated with the depression, the struggles against the owners of capital and the legitimacy of law breaking in this situation. The politics informing the story is from working class struggle (Apara's mother's family were socialists). In this way, Apara's experiences as a child are informed by a familial and collective past. The memory belongs to the family archive and is formative in her childhood, transmitting past events, a political position, a sense of pride and amusement.

National memories are selectively enacted in the celebrations that children engage with (or not), designed in particular interests. Children are positioned differently to each other in relation to these. Madhi remembers watching the Silver Jubilee celebrations on the TV. She is 5 or 6 , in the 1970s, of Indian heritage living in England. Her family are low paid, having moved from higher social status in India, then Kenya, before she was born,

There were these images of people ... on the streets. ... all white, all working class/middle class, eating food, with balloons ... I remember thinking, I don't know what this is all about, but we're not doing anything. Nobody where we lived [was] doing it, so it was just something on the TV. You just remember these mass produced teacups with the Queen's face on them.

Hobsbawm and Ranger (1983) argue that events such as this perpetuate stories about the social respect to be accorded certain people over others. They are a selective version of a remembered past. For relative newcomers, the national memories being celebrated relate to someone who ruled the British Empire. Madhi's family have different memories that cast different light on empire and royalty, stories related to oppression by the British in India,

I ... got this lovely story from my ... family. My grandfather used to get really pissed off ... with the British coming in and try and improve their rules, their laws, their culture, their lifestyle, when my grandfather thought 
we had our own one that was very dear to him ... So during times of curfew at night, my grandfather would go and stand on the rooftops. If there were any helicopters or anything going up in the sky, he would basically say in Gujarat, 'Tell them to Fuck Off!'

The Jubilee is not celebrated in Madhi's family and she feels an outsider, watching not participating. It is difficult to reconcile conflicting memories transmitted through her family and the wider society. This positions her at a distance, attempting to understand events through competing social frameworks (Halbwachs 1925/1992). Combinations of social memories are transmitted through family, community and nation. These create complex landscapes of social memory that children need to navigate.

\section{Navigating landscapes of memory in childhood}

Personal and social memories inter-relate and are hard to disentangle. The social landscapes children navigate are informed by social memories based around kin, community and nation (Lefebvre 1991, Massey 2005). Different forms of memory are visible in a turning point for Madhi, whilst she is visiting India in the 1980s. She is told by her father to hand out food to long lines of poor people. Aged 12 or 13, she struggles to cope; shocked by the condition in which these very poor people live. She somehow knows she should not display emotion,

'My dad decided that we were going to do some voluntary work ... it was on the river Ganges ... I was a really spoilt, young teenager... who couldn't stop fighting with my ... brother ... and acting like a right old pest ... Dad took us to do this thing and ... we had to feed the poor ... my Dad was putting food on the plate and I was giving them the plates ... This queue of hundreds of people ... I was gonna burst into tears ... I was like... "Don't you dare cry, because these people are homeless, hungry, have got nowhere to live, and you've been moaning endlessly"' ... I had this knot in my throat ... It was just horrible seeing that poverty... my Dad and I never really talked about why we did it ...'

This memory involves strong emotion at a personal level. In addition, it reveals the relationship with father, who encourages her participation; the passing on of familial memory to the British born girl this aspect of her Indian heritage. The tradition of giving to poor people is, in Halbwachs' (1925/1992) term, a collective memory of the better off in this society and religion (Hinduism) to assist the poor. The requirement to bury personal feelings is a strong part of the religious tradition; sublimation of self and personal desire. This is a response to poverty in an unequal society with little organised welfare. The place is highly significant; along the Ganges, a sacred place, where the tradition is enacted. Madhi 
experiences shame at her 'selfishness' and attempts to sublimate emotion to navigate this landscape.

Powerful social memories may be experienced with no intervening human agent. Richard is 11 in South Africa in the 1970s. His family moved from poverty and low paid employment in Manchester. They are white, hence more privileged under Apartheid. On his way from school he regularly crosses a foot bridge. White people are allowed to cross on one side, black people on another and there is a metal fence in the middle. Everyday he jumps this barrier and walks on the side meant for black people. He is not necessarily seen but the potential is always there. He is a bit scared each time, but far less so than a black child would be in similar circumstances where the consequences would be worse,

... there was a footbridge ... literally divided in half by a metal fence ... there was one side for the whites and one side for the blacks. You know they weren't even allowed to walk on the same bit of concrete across the footbridge. But what I remember doing ... I used to hop across and deliberately walk on the black side as my way of saying this was ridiculous - I always remember that, sort of deliberately hopping over the fence.

The design of the bridge contains a template for cruel behaviour. The memories of those that designed apartheid dominate the social landscape the child is experiencing. His route is prescribed and he transgresses these rules. ${ }^{3}$ However, his experience is not just informed by memories of designers of apartheid in the landscape. He has a counter-narrative from his family about the evils of apartheid,

....we were aware of things ... like the murder of Biko ... as a family ... we used to read the newspapers with the official police descriptions of what happened to people like Biko ... and there were others as well, you know they 'slipped on a piece of soap'...

This also underpins his feeling of disgust and informs this small act of resistance (jumping over also gives some physical pleasure).

Inequalities position children differently in the social landscape. The education they experience (the form of social memory they encounter) influences their powers to navigate and the direction taken. Particular pathways open and opportunities close. George lives in England in the early 1960s, of English working class heritage. He talks of his parent's work,

My first experience of work ...was ... my Dad's absence ... he would come in later, smelling of Brylcreem and sweat ... My second ... was going with ... mum when she was doing this cleaning to this posh house. So I associated work with, it was a bit exotic, going to a semi-detached 
house, with a back garden, rather than a yard, and they had a pet ... and reading Woman's Realm and posh biscuits, it's all kind of connected. ${ }^{4}$

The class and gender pathways involved in the landscape are visible. George's father is often absent at work. His mother moves from a working to a middle class neighbourhood ... to provide domestic service. George, for whom she is primary carer, sometimes goes with her. Many similar women have to leave their own children behind. The routes to work are laid out for women of her class. These are the 'spatial practices' informing the landscape, containing memories further back of many poorer women's journeys to work for better off families (Gregson and Lowe1994). George enjoys the garden, the women's magazines, the posh biscuits and the pet. As well as current pleasure, these are 'signs' of other possibilities he has not experienced, relating to social class, gender and sexuality. In Lefebvre's (1975/1991) terms, they are 'spatial representations' signalling the terms of entry to this space. George's mother, is providing domestic service and is permitted time-limited access to this more privileged home. George is curious and takes pleasure in the exotic experiences associated with his mother's paid work. The space is lived by the boy and is 'representational space' (ibid).

Although children navigate the landscape and the social memories conveyed there, through prescribed routes, they are able to transgress boundaries they encounter, through, for example, small resistances, inquisitiveness and play. Resources from the family inform the nature and direction of these journeys and the capacity to detour. Encounters on the way are formative for future times.

\section{Movement through space and time: encounters in childhood}

One memory may be part of several chains of memory leading to and from other people (Misztal 2003 citing Shils). The theme 'chains of memory' has a social dimension. It is a means of exploring connections in everyday childhood between present and past, individual and group and different places. 'Chains' imply something binding and metal so the concept has been replaced here by 'threads' of memory. These are woven in different ways, numerous strands may be threaded together and they may strong, fragile and malleable (Davies 1990).

When considering what is 'resonant' in childhood (sound, texture, smell, feeling) it is important to consider where this leads; the events connected and their significance for the present time of the child. When asked to remember war, Claudia, who had no direct experience, talks of darkness, silences and depressed feelings in the family, uncertainty and fear at school. Her parents, German and Romanian, moved to a village in England after the second-world war. It is early 1960s. She is 5, British born and working class, 
I don't think I was conscious of war per se ... but I remember being at primary school ... being conscious of being different ... people calling me names and perhaps not understanding things very well ... thinking that there was something not quite right ... I've got memories of talking to two boys about something, and I think that I was talking to them in German rather than English, or using words that were German, and them looking at me, as if I was weird ...that's a very powerful memory.

I'm also aware of anxieties at home ... there ... was a group of people ... that were all in POW camps over here ... they formed this sort of social club ...You know, with children, your conversations are like under the table ... it's hidden by the table cloth ...

These events are informed by threads of social memories from the past and different places, transmitted to her from her parents and school peers. Different social memories of war underpin the playground encounter creating uncertainty. Where does Claudia fit in the $2^{\text {nd }}$ world war games? Traumatic past events related to war, imprisonment and migration inform family life. The attempt to shelter the child from this has limited success,

... the language ... [my parents would] be speaking German ...I was probably quite fluent ... could understand a lot ... You'd know, if they definitely started talking German amongst themselves... you shouldn't be listening.

Claudia's parents' anxiety and lack of confidence arose from having being on the German side during the war. Although the brutalities of the $2^{\text {nd }}$ world war are past (15 years) they shape everyday events. Claudia is part of the 'post-war generation' but the residues of war are powerful and highly formative. Here everyday engagement involves weaving threads of memory from war. She learns not to ask her parents questions, 'I don't want to know what they think really,' takes pleasure in the lighter atmosphere in another child's house, '...I used to just love going round there... it was quite different, slightly chaotic, but very friendly and open and warm, which my parents house wasn't really...' Her mother will not let her join the Brownies (a quasi militaristic church based girl's organisation),

My mum absolutely forbad me to go, because she thought it would cost money, and was really uncertain about it. Now whether it was anything else, whether she was reflecting back on her own youth, and the Hitler youth, I don't know.

Threads of social memory are passed through networks of kin, artefacts, institutions, ceremonies and other social arrangements. So there are powerful effects when children move between places. These threads are disrupted through migration. Coser (in Halbwachs /19251992: 21) argues that migration 
may involve people having to 'shed their own collective memory like a skin'. Rehana lives in Pakistan in quite a privileged household as a child. She remembers migrating to England aged 11 or 12. It is the 1960s and her father is with her. All her siblings have preceded her; '... my dad brought us in bits and pieces'. Many parties have been held in Pakistan to mark her leaving. She sits on the plane,

I felt very hollow inside as if something had been removed from my guts. I had that feeling of emptiness, something hollow in me, as if one chapter of my life, I'm leaving behind. So many happy, sad memories ... when would I be able to go back and see them and what would it be like? It's a very strange feeling, thinking that ... I was very quiet ... I kept going to the aeroplane toilet and reading my friends' letters, saying all nice things to me, 'Don't forget us', 'Write to us' ... little poems in them for me... it was a night flight so the plane was dark ... just reading all these letters to keep myself moved, to keep as if I was still in touch, not letting go of the memories.

Rehana attempts to anchor memories of the people she is leaving behind. Although looking forward to joining her siblings, she fears a tailing away of social memories of friends in another place and time.

'Arriving in a new place means joining up with, somehow linking into, the collection of interwoven stories of which that place is made' (Massey 2005 p.119). Such stories relate to environmental as well as social change. Apara and Richard migrated at a similar age (4 or 5). They convey the physical as well as social experience of arrival. Apara comes from Nigeria to Northern England,

... it was real fog, and l'd never seen fog like that and it was ... standing on one side of the road ... you couldn't see the little green man when it was time to cross the road ... it was only the sound,

Richard arrives in South Africa from Manchester,

It was boiling hot ... standing in this place ... the shimmering heat ... when you look across .and the horizon is sort of moving and shimmering with the heat... and the cattle with the long horns.

The pathways these children follow after arrival are different. Richard gains some economic and social privileges as a white child. Apara faces racial violence in the white working class neighbourhood where her family moves. Both societies are informed by racial and class hierarchies that position children differently according to colour. Some of the wide social arrangements these children experience may appear fixed and unchangeable, the processes giving rise to these arrangements are only visible to the children when they are told about them. 


\section{The implications for children of silence in the social memory}

Children's experience may remain silent, insufficiently informing social memory. First, children have little power to be heard, important experiences remain unarticulated. Secondly, experiences may be trivialised in ways that suit particular interests. Thirdly, there may be insufficient social frameworks for them to understand and describe what is happening (Halbwachs 1925/1992). Fourthly, social arrangements may be taken for granted, a naturalised part of childhood (ideas about biological and therefore social differences between boys and girls are an example) (Haug 1992). Some institutions and ideas become so imbued with authority that many aspects of the trajectories that gave rise to them remain invisible. These are 'fossils' in the social memory (Halbwachs 1925/1992). Unless events are democratically interpreted in the interests of and involving children, they form part of the social landscape that is hard for children to navigate.

Julie and Lara were both attacked in their early teens. Julie is of white English working class birth and heritage. Her mother is very ill in hospital. She is standing at a bus-stop in the mid 1960s,

I remember being flashed ... in a bus queue ... I was 14 or 15 maybe. Allowed to go to town on my own on the bus and I think l'd got to the stage where every Saturday morning l'd go and do a little bit of wandering round town ... I was stood ... in the middle of a bus queue, and there's this guy with a Mac behind me, playing with himself when I turned round, and you just think you're imagining things, or you think it's your fault. It was probably years before I told anyone.

Lara is English born, of Caribbean - Italian heritage and working class. She remembers standing at a bus-stop in the 1970s,

I [aged 13] was just waiting for the bus ... just stood, like everyone else, waiting for the bus, and National Front rally going on, at city square, as they did in those days, and a few of them must have come down ... I was totally oblivious ... the next minute, l'd been kicked and punched on the floor by these grown men ... I was only a tiny, little, skinny girl... if it wasn't for the police, I don't know what would have happened. [The police took her to hospital; the men were arrested and prosecuted]

Both these children may have been targets because of their lack of physical and social power. The sexual attack remains unarticulated for many years. The racial attack has to be acted on because of Lara's physical injuries. Julie is very confused and has no framework to understand the sexual attack. She may be relating it to her own sexuality, '....or you think it's your fault'. Lara is more prepared but still deeply shocked, '... my mum used to always say to us, "Don't 
ever walk with your head down. Always walk with your head straight up, and look somebody straight in the eye. Cause the minute you drop your head, you're vulnerable". Both attacks are minimised through the social frameworks available to understand and challenge events. The terms 'flashed' and 'playing with himself' are social clichés that minimize the sexual abuse of Julie (Haug 1992). The National Front 'rally' provides a context for the attack on Lara where they gathered clearly incite each other to racial violence. The police men support Lara but the weekly 'rally' remains un-policed. The term 'rally' reduces social understanding of the purpose of this gathering. The fossils (Halbwachs 1925/1992) in social memory at the time of both these attacks are the social hierarchies related to gender, 'race' and childhood. Both attacks aim to keep particular children in their place. For Julie and Lara, their capacity to deal with these attacks emotionally relates to the social frameworks available from the family and wider society. These enable them to articulate the experience (or not) defend themselves and be socially protected. Silences and distortions that arise in the social memory prevent this.

\section{Carving space-time out for self in childhood}

Two children's experiences are now discussed to demonstrate that despite the barriers and silences so far discussed, children are creatively engaged in carving out space and time for themselves. Rachel is British born, of mixed working and middle class heritage, growing up in the 1970s-80s. She gives two examples of negotiating clothing in relation to her emerging social identity. First, aged 11,

We had a leaving do at the end of primary school .... all the parents got written to say we're having this disco ... this is the dress code. Girls will be wearing skirts and dresses, boys must wear smart trousers ... I just said, "I'm not going." The thought, by that point in my life, of having to wear a skirt or a dress, was so traumatic for me... My mother had battled with me prior to that, to send me to children's parties, in the party frocks, The last one of which I came home with it rolled up under my arm, I'd been up a tree the whole time ... with frilly knickers! And all the lace was hanging off, and I was covered in dirt.

This is a time of transition, to mark the end of one stage of schooling where the clock times of school are relaxed and the school admits pupils in the evening. The dress code regulates how these children will behave, even in this freed up space-time. 'Clichés' of respectability and gender come to these children from the wider society. They are expected to wear clothes that are 'fossils'; representing ideas of what children should wear that were generated in past times (in another higher social class). Rachel fiercely rejects this apparel alongside the associated 'girly; identity. Later, her clothing choice is freer,

I became a bit of a 'New Romantic' once that all kicked off, with all the scarves and the pirate look, that was an identity. That was quite fluid 
gender wise, that was something I became quite aware of, so you had Boy George and Alison Moyet and you didn't know whether they were male or female, and that was like, wow, that's really interesting, I like that.

The choice of gender fluidity in fashion reflects Rachel's sexuality at 15 (she knows she is a lesbian) together with her thoughtfulness in dressing. To some beholders her sexuality is blurred (to others not) and the fashion is captivating. She selects this clothing with reference to her own feelings, peers and cultural signals. Clothing previously prescribed in relation to class and gender respectability is now chosen in relation to a desire for gender and class fluidity. Clothing is intensely negotiated (both individually and in groups) because it involves a presentation of self to others. Her negotiation of clothing intersects with social ideas about respectability from interconnected systems related to gender, class, race and religion. The global popular culture industries have presented some fashion options. Out of this Rachel carves space and time for herself and avoids forms of social labelling (Lees 1993)

Cathy talks of her engagement with religious practices as a child. She is British born, of working class heritage, growing up in the 1960s-70s. Her parents both work long hours for low pay, hence she and her sister are relatively unsupervised and carve their own routes through the local community. This brings them in touch with different religious practices. This is a time of conflict in Northern Ireland and there are powerful associations in Liverpool. Cathy's family is (technically) Protestant. She remembers being taken to Orange Lodge celebrations in the park,

... I do think of orange, this vivid colour, and I guess, in my memory, it was like a church fete, that kind of atmosphere ... I remember the kind of bands. The music associated with it and how it was very enjoyable, it was a good sing. It was like, "Oh the Orange Lodge are here". I had no notion of, of course, of what it was about at that age...

She also regularly visits a convent because of her links with an Irish Catholic neighbour,

She'd come over from Liverpool after the Dublin Uprising [in 1917]. We became almost honorary Catholics ... We lived in the terraced houses ... but there was this huge convent at the top of the road... These little girls of 9 and 7, there'd be a secret knock and this door would open... these huge high walls ... we would be stood there, and a nun, in full regalia would be stood, "Ah sure ... come on in girls," and you'd come in, ... you'd see the door close behind you ... it was always as if there was nothing outside, you'd come into this completely different world.

Then away from the convent and back in the terrace houses, 
Sometimes the nuns would come to Aunty [Mary's] house... and draw the curtains ...then we'd be sat, in this little Séance environment ... clearly frightened, "What's going to happen now?" But actually, all it was about was that the nuns wanted to have a swill of sherry ... they didn't want anyone to see!! So this image of the 2 or 3 nuns crowded in this tiny terrace house, knocking back the sherry...

Cathy sits outside the sectarianism of religious practices that surround her. Had she been living in Northern Ireland at this time, she would have been more locked into one religious community, her movement more limited. James talks about growing up there during the Troubles in the 1960s-1970s,

.... predominantly Protestant community, my family were very ... religious. My dad was ... also very pro the Orange Order ... So I learned from that and was very pro that, and ...very aware ... there is no back out clause. You're in or you're not in and that's it.

As a children both Cathy and James are involved in religious practices grounded in times past, including forms of worship, celebration and the re-enactment of conquest. Later knowledge about the Troubles casts a shadow. These religious practices sustained conflict into the future, celebrating, for example, William of Orange's victory over the Catholic King James in 1690. The children carve space and time for themselves in different ways. For Cathy religious practices provide pleasure, mystery, fear, confusion and a sense of awe. For James, in addition, there is a deep sense of belonging that pulls him into conflict,

Proud to be part of that ... it's more than civic pride, it's more a national pride .... Very, very proud of your identity and your culture and defended that, physically, on many occasions as well.

Children's navigation of the social landscape involves a range of complex engagement and the carving of space-time for self. Neale and Flowerdew (2003: 192) argue that complex relations of time form the textures of children's everyday lives and 'the interplay of time and texture' is an important route of research analysis to give visibility to their engagement in adult worlds. Social arrangements (fashion or religion) are understood and shaped by the past, are lived in the present and the way they are lived has implications for the future. Children are involved in those processes. Their circumstances place them in a particular relation to these arrangements and they carve out space-time accordingly. Children's everyday action involves the turns and twists of time (Neale \& Flowerdew 2003) including events directly experienced and the longer times (Giddens 1991) of institutions and the environment. They are not separated from these processes but actively involved. ${ }^{5}$

\section{Conclusion}


This article has discussed the approach in the Pathways through Childhood research, a project concerned to illuminate children's experience of social events and arrangements (war, migration, religion and so forth) that have been underresearched. Such experience has been of concern in relation to particular groups of children (refugees for example) less so, children in general. It has been argued that research methodology that gives attention to children's part and place in the landscape (involving complex relations of space, time and social memory) uncovers important (sometimes distant) social influences, different routes and pathways, and different sorts of engagement related to their position and circumstances.

Children are directly involved in wide social experience; social arrangements and events are constructed and interpreted through familial and collective memory. Giving attention to the temporal and spatial complexity of childhood reveals some less visible formative connections in their everyday lives. These include connections between past and present time, between children, families, communities and nations, and between different places. Children carve out space and time for themselves from this complex social landscape.

$27^{\text {th }}$ May 2009

\section{End Notes}

${ }^{1}$ The funding was $£ 2000$ (UK) , Carnegie Research Institute, Leeds Metropolitan University

${ }^{2}$ Working in retrospect with adults remembering childhood involves the complexity of drawing on adult reminiscences as research data or 'pockets of history' (Brannen 2004: 425). Frameworks for social memory (Halbwachs 1925/1992) vary according to time-perspectives (Brannen 2004).

${ }^{3}$ Memories are imbued with knowledge of the present and of the past (Jaques 1982/1990). Events associated with strong emotion may be recalled easily - or may be buried. The selection of memory relates to the contemporary lives of participants.

${ }^{4}$ When the process of remembering is considered at a personal level, these memories are clearly drawn from clusters of events including absences and 
presences, smells, tastes and journeys. There is some pleasure in the memories. There may be aspects that are faulty.

${ }^{5}$ Time perspectives inform the versions of childhood remembered and generation influences this (Brannen 2004). Analysis of the time perspectives shaping memory draw attention to the different ways in which childhood is socially constructed. 


\section{References}

Adam, B. (1990). Time and Social Theory. Cambridge: Polity.

Adam, B. (1995) Timewatch: The Social Analysis of Time. Cambridge: Polity.

Adam, B. (1998) Timescapes of Modernity. The Environment and Invisible

Hazards. London: Routledge.

Adam, B (2006) Time in Theory Culture and Society 23 2-3 119-138

Aitken, S. (2001) Geographies of Young People: The Morally Contested Spaces

of Identity. London: Routledge.

Ardener, S. (Ed.) (1993) Women and Space. Ground Rules and Social Maps.

Oxford: Berg.

Brannen, J. (2004) Childhoods across the generations storied from women in four-generation English families. Childhood 11, 4, 409-428.

Davies, K. (1990) Women and Time. The Weaving of the Strands of Everyday Life. Aldershot: Avebury 
Jaques, E (1982/1990) The Enigma of Time. In J. Hassard (Ed.) The Sociology of Time. London: Macmillan.

Giddens, A. (1991) Structuration theory: past, present and future. In C. Bryant and D. Jary (Eds.) Gidden's Theory of Structuration. A Critical Appreciation, London: Routledge.

Gregson, N. and M. Lowe (1994). Servicing the Middle Classes: Class, Gender and Waged Domestic Labour. London: Routledge.

Halbwachs, M (1925/1992) On Collective Memory In L. Coser (Ed.) University of Chicago Press.

Haug, F. (1992) Beyond Female Masochism. Memory - Work and Politics. London: Verso.

Hobsbawm, E. and T. Ranger (Eds.) (1983) The Invention of Tradition. Cambridge University Press.

Holloway, S. L. and Valentine, G.(2000) Children's Geographies, Playing, Living, Learning London, Routledge Layder, D. (1993) New Strategies in Social Research. Cambridge: Polity. Lees, S. (1993) Sugar and Spice. Sexuality and Adolescent Girls. Harmondsworth: Penguin.

Lefebvre, H. (1972/1991) The Production of Space. Oxford: Blackwell. Massey, D. (2005) For Space. London, Sage.

Misztal, B. (2003) Theories of Social Remembering. Maidenhead: Open University Press. 
Morrow, Virginia (2003) 'Moving out of Childhood', in Janet Maybin and Martin Woodhead (eds) Childhood in Contexts, 267-301.Milton Keynes: Wiley and Sons, Open University.

Neale, B. and J. Flowerdew (2003) Time, texture and childhood: the contours of Iongitudinal qualitative research. International Journal of Social Research Methodology 6, 3, 189-199.

Rose, Gillian, (1993) Feminism and Geography. The Limits of Geographical Knowledge. Cambridge: Polity.

Saraswathi, T. S., (1994) 'Women in Poverty Contexts', in Romy Borooah, Kathleen Cloud, Subodra Seshadri, T.S. Saraswathi, Jean T. Peterson and Amita Verma. (eds) Capturing Complexity. An Interdisciplinary Look at Women, Households and Development. London: Sage.

Thomson, Rachel, Bell, Robert, Holland, Janet, Henderson, Sheila, McGrellis, Sheena and Sharpe, Sue (2002). 'Critical Moments: Choice, Chance and Opportunity in Young People's Narratives of Transition. Sociology 36, no 2: 335354.

Urry, J, (1991) Time and Space in Gidden's Social Theory, in Christopher Bryant and David Jary (eds.) Gidden's Theory of Structuration. A Critical Appreciation, London: Routledge.

Urry, J. (1996) "Sociology of Time and Space" in Bryan S. Turner (ed) The Blackwell Companion to Social Theory. Oxford: Blackwell. 